\title{
Stingless bees and mass flowering trees in the canopy of Atlantic Forest: a tight relationship
}

\author{
Mauro Ramalho ${ }^{1}$
}

Received: September 9, 2001. Accepted: July 27, 2003

\begin{abstract}
RESUMO - (Abelhas sem ferrão e árvores com floradas maciças na Mata Atlântica: uma relação estreita). As pequenas abelhas sem ferrão ou meliponíneos (Apidae, Hymenoptera) representam cerca de 70\% de todas as abelhas em atividade nas flores em uma área de Floresta Tropical Atlântica. Além disso, concentram o forrageio nas flores do estrato superior. Propõe-se a hipótese de que esta distribuição vertical resulta da distribuição desigual de suas fontes florais preferidas nos estratos da floresta. No estrato superior, a maioria das árvores intensamente visitadas pelos meliponíneos apresenta flores nectaríferas, pequenas e inconspícuas, com morfologia generalizada (simetria radial e corola aberta), reunidas em grandes inflorescências. Em geral, essas árvores são hermafroditas ou monóicas e suas copas tendem a apresentar floração maciça (isto é, numerosas flores abrem-se a cada dia). Como mais de $70 \%$ dos meliponíneos concentraram o forrageio nessas árvores, foi reexaminada a hipótese de que a abundância dessas abelhas generalistas estaria relacionada à abundância de árvores dióicas na floresta tropical pluvial. Desenvolve-se o argumento de que os meliponíneos facilitam a auto-polinização (autogamia ou geitonogamia) e, ocasionalmente, participam da polinização cruzada de árvores com florações maciças. A relação ecológica estreita dos meliponíneos com as floradas maciças envolve possível co-evolução difusa, com gradual substituição de outros polinizadores generalistas, imprevisíveis e pouco eficientes no dossel da floresta tropical.
\end{abstract}

Palavras-chaves: abelha sem ferrão, dossel, estratificação, floração maciça, Mata Atlântica

\begin{abstract}
Stingless bees and mass flowering trees in the canopy of Atlantic Forest: a tight relationship). This study demonstrates that stingless bees (Apidae, Hymenoptera) amount to approximately $70 \%$ of all bees foraging on flowers in the Brazilian Tropical Atlantic Rainforest. They also are the unique bee group concentrated in the upper stratum. It is hypothesized that this vertical distribution is a result of an uneven distribution of preferred floral resources within the forest strata. In the upper stratum, most of the trees that are highly visited by stingless bees produce small, inconspicuous, generalized flowers, clustered in dense inflorescences (mass flowering). These trees represent only $15 \%$ of the total melittophilous flora in the study area (96 plant species). In contrast, they attracted all 17 stingless bee species and more than $70 \%$ of all stingless bee individuals. Almost all these mass-flowering trees are hermaphroditic or monoecious, therefore the hypothesis that the stingless bees would be related to the abundance of dioecious trees in tropical rainforests was reexamined. It is proposed that small generalist stingless bees facilitate self-pollination and occasionally cross-pollinate these mass flowering trees. The tight relationship between stingless bees and mass-flowering trees is more properly in the center of a diffuse coevolutionary process, with the gradual replacement of other unpredictable, generalist and poor pollinators (e.g. small beetles) at the forest canopy.
\end{abstract}

Key words: stingless bees, forest canopy, foraging stratification, mass flowering, Atlantic forest

\section{Introduction}

Stingless bees (Apidae, Hymenoptera) probably arose as a pivotal ecological force within tropics at the end of the Cretaceous period (Michener \& Grimaldi 1988). Nowadays, the ecological dominance of stingless bees among insects visiting flowers in the Neotropical lowlands has been attributed to their high eusociality, perennial colony activity, and generalized food habits (Michener 1979; Roubik 1992). They represent 5 to $25 \%$ of the total bee species (Apoidea) present in the dry to wet, and less seasonal forests of Central America (Roubik 1993a). In South America, there is evidence of the numerical dominance of stingless bees among the bee fauna within forests, savannah and other openvegetation habitats (Bortoli \& Laroca 1990; Barbola \& Laroca 1993; Silveira et al. 1993; Martins 1994; Silveira \& Campos 1995; Wilms et al. 1996; Aguiar \& Martins 1997; Viana et al. 1997).

Contrasting to their generalized food habits, stingless bees are likely to be dependent on the exploitation of rich floral sources of pollen and nectar, in order to maintain a large perennial colony biomass and a high turnover of foragers throughout the year. Therefore, abundance distribution of stingless bees on flowers would be key measurements for the analysis of

\footnotetext{
1 Instituto de Biologia, Universidade Federal da Bahia, R. Barão de Geremoabo s/n, CEP 40170-210, Ondina, Salvador, BA, Brasil (ramauro@ufba.br)
} 
their pollination role and ecological pressure on available floral resources in tropical communities. These arguments are examined using field data on bee distribution within an area of Tropical Atlantic Rainforest in Brazil.

Vertical distribution is probably another important component of foraging activities of bees in tropical forests (Frankie \& Haber 1983; Roubik 1993b; Roubik et al. 1995) with unknown selective effects on flowering strategies and plant reproductive systems (Kress \& Beach 1994). Roubik (1993b) suggested that the unpredictable stratum-orientation of stingless bees was an outcome of their opportunistic foraging. Alternatively, the present study explores the possibility that the vertical distribution of stingless bees is a predictable result of the uneven distribution of rich floral sources within the forest strata in the Atlantic rainforest.

Finally, the abundance distribution of stingless bees on flowers and related data on plant sexual systems in the Atlantic rainforest are used to examine the following controversial arguments. First, Roubik (1992; 1993a) proposed that stingless bees are pre-adapted to preempt niches of other flower visitors as these bees seem to appropriate most of the pollen and nectar rewards of melittophilous flowers in tropical forests (Roubik 1993a). As a result, floral niches have become relaxed (loosen) in the humid tropics, where the stingless bees have been playing a role as generalized pollinators. Second, Wilms et al. (1997), in contrast, suggested that the diffuse co-evolution of stingless bees and flowers in Tropical Atlantic Rainforest could explain the abundance of plant species with small flowers clustered in rich inflorescences (mass flowering). Third, Bawa (1980; 1990) hypothesized that these abundant but inefficient cross-pollinators may be related to a high frequency of dioecious tree species in tropical forest. All these inferences are fragile, however, because they lack correlated field information on plant reproductive systems and on the role of stingless bees in pollination, which are discussed here.

\section{Material and methods}

Study site - The study site was a Tropical Atlantic Rainforest (TAF) fragment of approximately 10,000ha located on the São Paulo plateau (2322'S, $46^{\circ} 26^{\prime} \mathrm{W}$ ), Brazil. Historical data, phytosociologic studies, and the presence of large mammalian species, such as a large local population of howler monkeys, Alouatta fusca, a canopy inhabitant, indicates that the study site represents a remnant of the original continuous Atlantic Rainforest along the Serra da Cantareira mountains (Por 1992; Baitello et al. 1993). The altitude ranges from between 800 and $900 \mathrm{~m}$. The average temperature during the hottest month (February) is $21.3^{\circ} \mathrm{C}$, and the coldest (July) is $14.7^{\circ} \mathrm{C}$. Annual rainfall is approximately $1,600 \mathrm{~mm}$. There is no dry season in that region.

Bee sampling and vertical distribution analysis - During one day per week, from March/1993 to October/1994, and from January/1997 to July/1997, bees were collected using a telescopic handle net along a transect $6 \mathrm{~km}$ long and $50 \mathrm{~m}$ wide, covering a total area of $30 \mathrm{ha}$. Tree crowns higher than $8 \mathrm{~m}$ were reached by using climbing ropes. Due to the concentration of mass-flowering trees over $7 \mathrm{~m}$ height, this vertical limit was empirically used to establish the inferior range of the upper stratum. It was estimated that floral resource availability is one to two orders of magnitude greater in the upper stratum than in the lower stratum, due to the rarity of mass-flowering crowns below $7 \mathrm{~m}$ height in the TAF.

Bees were sampled on flowers from 7:00 a.m. to 5:00 p.m. during 5 to 60 minute periods at each tree (or grouped specimens of herbaceous plants) depending on its flowering surface: 5 minutes for a flowering surface up to $2 \mathrm{~m}^{2} ; 15$ minutes for a flowering surface from 2 to $4 \mathrm{~m}^{2} ; 30$ minutes on a flowering surface from 4 to $9 \mathrm{~m}^{2}$, and 60 minutes if the surface was greater than $9 \mathrm{~m}^{2}$. Consequently, more sampling was undertaken in the upper stratum (58h) than in the lower (39h).

The distribution of bee specimens between the upper $(\geq 7 \mathrm{~m})$ and the lower $(<7 \mathrm{~m})$ stratum were compared using the chi-square-test. Complementary and detailed parametric analysis of vertical distribution of the most abundant stingless bee species is presented in other paper (Ramalho et al. in prep.).

Bee plants - The number of stingless bee individuals sampled while visiting each plant species was totaled, and the group of plant species, which accounted for more than $70 \%$ of the individuals sampled in the TAF were defined as "highly visited". Mass-flowering pattern was determined considering a rough estimate of flowers produced and opened at each moment in each individual crown in relation to the range of its flowering period (Gentry 1974a,b). An arbitrary characterization of the degree of mass flowering of the highly visited plants was proposed, according to the ratio between flowering surface and canopy surface at flowering peak: moderate (1/4 to $1 / 2)$; high (1/2 to $3 / 4)$, and very high ( $>3 / 4)$. Plants often visited by bees were designated as "bee plants" 
even if they failed to exhibit a classical melittophilous floral syndrome.

Bees and plants identification and Bee list - Bees were identified by Dr. Jesus Santiago Moure (Universidade Federal do Paraná, UFPR) and Dr. João Maria F. Camargo (Universidade de São Paulo, USP-RP/SP), beetles by Dr. Sérgio Vanin (USP, SP), and the plants by Dr. Waldir Mantovani (USP, SP). All specimens were added to the collections at the "Bee Lab PNN" (USP). Plant species were deposited at the herbarium of the Universidade de São Paulo (SPF).

The bee groups cited in the results and discussion are listed in Table 1.

\section{Results}

Foraging stratification in the Tropical Atlantic Rainforest (TAF) - In the Tropical Atlantic Rainforest, the association between bee groups and strata were significant, although strata preferences were not identical among these groups (Tab. 2). While stingless bees (Meliponinae) were numerically dominant in all strata, they represented approximately $80 \%$ of all foraging individuals in the upper stratum and $45 \%$ in the lower. The opposite was true for the non-Apidae groups: altogether they represented around $10 \%$ and $35 \%$ of foraging individuals in the upper and the lower strata, respectively.

Megachilidae and some Anthophoridae were notable for their higher numerical abundance in the lower stratum, where they represented approximately $8 \%$ and $16 \%$ of the sampled bee individuals. In the upper stratum, these two bee groups accounted for less than $5 \%$ of all foraging individuals (Tab. 2). The apparent uniform distribution of Halictidae is a sampling artifact: considering the total number of Apoidea sampled in each stratum, it should be expected a significantly higher number of Halictidae bees foraging in the upper strata.

Among the eusocial Apidae species (Fig. 1), there was a concentration of Apis mellifera $\mathrm{L}$. foragers higher than expected in the lower strata $\left(\chi^{2}=98.8 ; \mathrm{f}=1\right.$; $\mathrm{p}<0.001$ ). Bumblebees (Bombus brasiliensis Lepeletier, and Bombus morio Swederus) were also more common in the lower stratum, often visiting large-flowered species of small trees, shrubs and herbs. With the exception of Trigona fulviventris and T. spinipes, the other stingless bee species were associated with the upper stratum $\left(\chi^{2}=96.6 ; \mathrm{df}=10 ; \mathrm{p}<0.001\right)$.
Paratrigona subnuda and Scaptotrigona bipunctata were numerically dominant overall, accounting for approximately $80 \%$ of all stingless bee

Table 1. Bee taxa discussed in the text, and abbreviations used in Tables and Figures. The eusocial Apidae species are determined. To the other bee genera are assigned only the number of species (in brackets) sampled in the Tropical Atlantic Rainforest.

\begin{tabular}{|c|c|}
\hline Bee Taxa & Abbreviation \\
\hline \multicolumn{2}{|l|}{ ANTHOPHORIDAE } \\
\hline Centris (4 spp.) & $\mathrm{Cn}$ \\
\hline Ceratina (8 spp.) & $\mathrm{Ce}$ \\
\hline Ceratinula (5 spp.) & $\mathrm{Ct}$ \\
\hline Exomalopsis (4 spp.) & $\mathrm{Ex}$ \\
\hline Paratetrapedia (5 spp.) & Pte \\
\hline Tetrapedia (2 spp.) & $\mathrm{Te}$ \\
\hline \multicolumn{2}{|l|}{ APIDAE: MELIPONINAE } \\
\hline Geotrigona subterranea Friese & Gs \\
\hline Melipona bicolor Lepeletier & $\mathrm{Mb}$ \\
\hline Melipona marginata Lepeletier & $\mathrm{Mm}$ \\
\hline Melipona quadrifasciata Lepeletier & $\mathrm{Mq}$ \\
\hline Melipona rufiventris Lepeletier & $\mathrm{Mf}$ \\
\hline Nannotrigona teataceicornis Lepeletier & $\mathrm{Nt}$ \\
\hline Paratrigona subnuda Moure & Os \\
\hline Partamona helleri Friese & $\mathrm{Ph}$ \\
\hline Plebeia droryana Friese & $\mathrm{Pd}$ \\
\hline Plebeia remota Holmberg & $\operatorname{Pr}$ \\
\hline Scaptotrigona bipunctata Lepeletier & $\mathrm{Sb}$ \\
\hline Schwarziana quadripunctata Lepeletier & $\mathrm{Sq}$ \\
\hline Tetragona clavipes Fabricius & $\mathrm{Tc}$ \\
\hline Tetragonisca angustula Latreille & $\mathrm{Ta}$ \\
\hline Trigona fulviventris Guérin & $\mathrm{Tf}$ \\
\hline Trigona hyalinata Lepeletier & Th \\
\hline Trigona spinipes Fabricius & Ts \\
\hline \multicolumn{2}{|l|}{ APIDAE: APINAE } \\
\hline Apis mellifera $\mathrm{L}$. & $\mathrm{Am}$ \\
\hline \multicolumn{2}{|l|}{ APIDAE: BOMBINAE } \\
\hline Bombus brasiliensis Lepeletier & $\mathrm{Bb}(\mathrm{Bo})$ \\
\hline Bombus morio Swederus & $\mathrm{Bm}(\mathrm{Bo})$ \\
\hline \multicolumn{2}{|l|}{ COLLETIDAE } \\
\hline Colletes (3 spp.) & $\mathrm{Co}$ \\
\hline Hylaeus (11 spp.) & Hy \\
\hline Halictandrena (1 sp.) & Han \\
\hline Lonchopria (2 spp.) & $\mathrm{Ln}$ \\
\hline \multicolumn{2}{|l|}{ HALICTIDAE } \\
\hline Augochlora (18 spp.) & Ac \\
\hline Caenohalictus (5 spp.) & $\mathrm{Ch}$ \\
\hline Dialictus (9 spp.) & $\mathrm{Di}$ \\
\hline Habralictus (4 spp.) & $\mathrm{Hb}$ \\
\hline Neocorynura (5 spp.) & $\mathrm{Nc}$ \\
\hline Paroxystoglossa (1 sp.) & Px \\
\hline Rhynocorynura (2 spp.) & $\mathrm{Rc}$ \\
\hline \multicolumn{2}{|l|}{ MEGACHILIDAE } \\
\hline Anthodioctes (2 spp.) & Ant \\
\hline Coelioxys (3 spp.) & $\mathrm{Cx}$ \\
\hline Megachile (16 spp.) & Mch \\
\hline Paranthidium (2 spp.) & Pan \\
\hline
\end{tabular}


Table 2. Contingency table relating Bee Taxa and Strata in the Tropical Atlantic Rainforest. Expectations are in brackets. $\left(\chi^{2}=\right.$ 872.1; df $=5 ; \mathrm{p}<0.001)$.

\begin{tabular}{lll}
\hline \multirow{2}{*}{ Bee Taxa } & \multicolumn{2}{c}{ Forest Stratata } \\
\cline { 2 - 3 } & Upper $(>7 \mathrm{~m})$ & Lower $(<7 \mathrm{~m})$ \\
\hline $\begin{array}{lll}\text { Colletidae }(\mathrm{n}=18) \\
\quad \text { Andrenidae }(\mathrm{n}=6)\end{array}$ & $144(129)$ & $29(44)$ \\
Halictidae $(\mathrm{n}=55)$ & $114(168)$ & $112(57)$ \\
Megachilidae $(\mathrm{n}=26)$ & $43(132)$ & $134(45)$ \\
Anthophoridae $(\mathrm{n}=44)$ & $199(348)$ & $269(119)$ \\
Apidae/Meliponinae $(\mathrm{n}=17)$ & $4,004(3,588)$ & $815(1,230)$ \\
Apidae/other $(\mathrm{n}=3)$ & $471(609)$ & $347(209)$ \\
Total-Apoidea $(\mathrm{n}=169)$ & 4,975 & 1,706 \\
\hline
\end{tabular}

foragers sampled on flowers in the Cantareira Forest (Fig. 3). Both species are significantly related with the upper stratum. More than $80 \%$ of the individuals of both species were encountered in the upper stratum (Fig. 1) Moreover, the high abundance of both bee species in the upper stratum is related with their patchy foraging on a small number of tree species: the highly visited mass-flowering trees.

The vertical distribution of both bee species is related with the availability of flowering plants in forest strata in a subtle different way (Fig. 2): less than $2 \%$ of the individuals of $S$. bipunctata and around $15 \%$ of the individuals of $P$. subnuda were encountered in the lower stratum. Small numbers of $P$. subnuda were sampled in the upper stratum only during shortage periods of mass flowering, or during periods of high availability of attractive flowering herbs in the lower stratum (Tab. 3, Fig. 2). By contrast, S. bipunctata was rarely found on flowers in the lower stratum throughout the year.

The other five locally abundant stingless bees ( $\mathrm{N}>100$; Fig. 3) did not exhibit the same pattern of

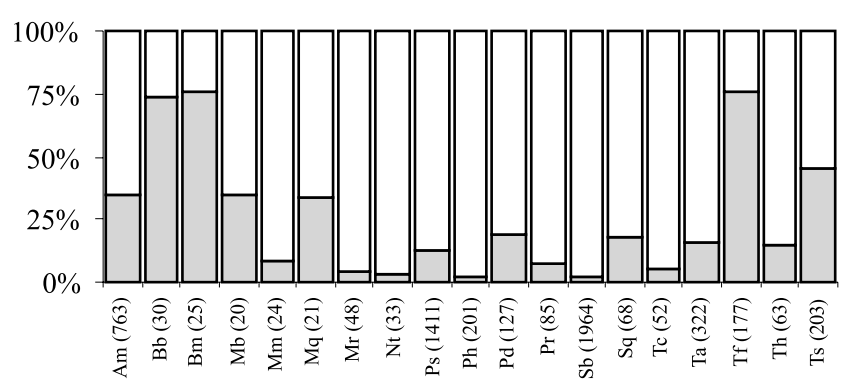

Figure 1. The association of eusocial Apidae bees (stingless bees, Apis and Bombus) with the upper and lower strata in the Tropical Atlantic Rainforest. Pooled annual data $\left(\chi^{2}=872.9 ; \mathrm{df}=17 ; \mathrm{p}<0.001\right)$. All bee taxa and abbreviations (abscissa) are listed in Tab.1. lower; $\square$ upper. 2a. Paratrigona subnuda

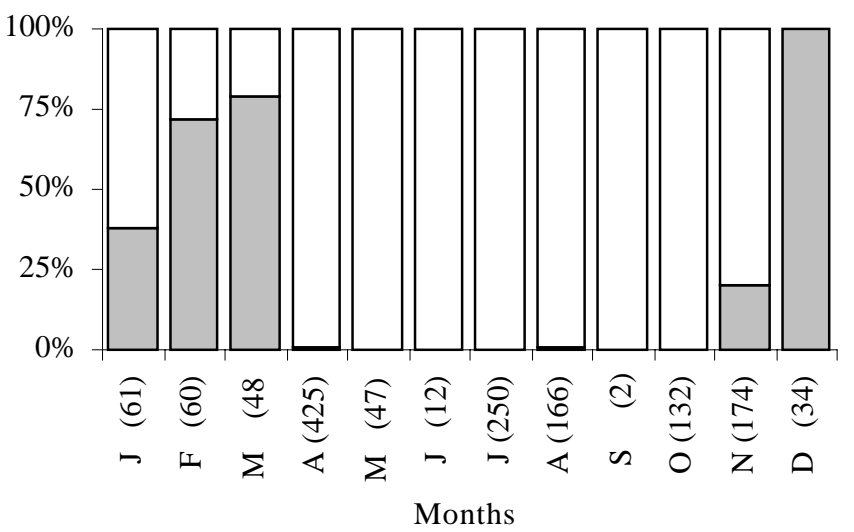

2b. Scaptotrigona bipunctata

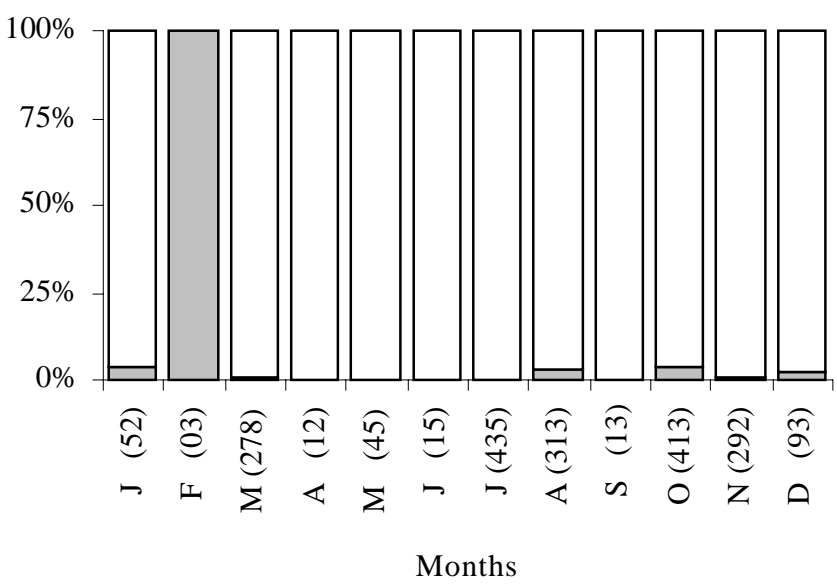

2c. Bee plants

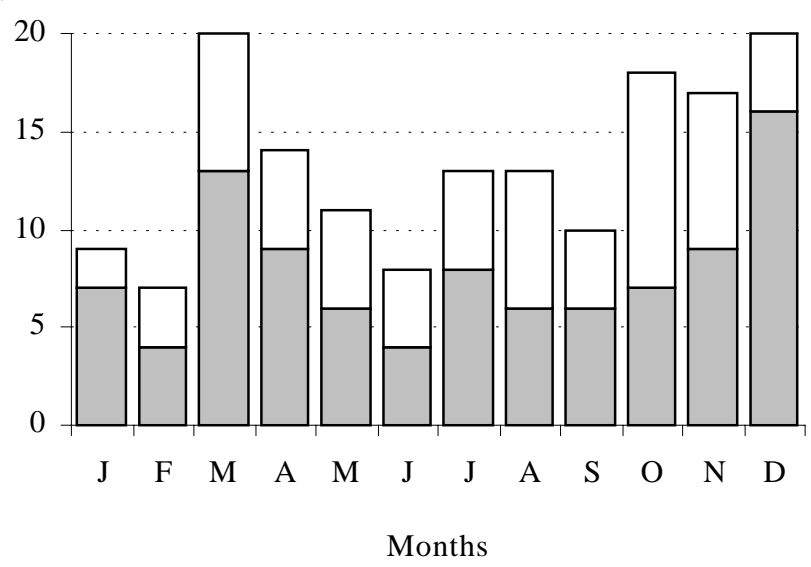

Figure 2. Foraging stratification of the dominant stingless bees in the Tropical Atlantic Rainforest. Pooled monthly data for (a) Paratrigona subnuda $\left(\chi^{2}=495,9 ; \mathrm{df}=1 ; \mathrm{p}<0.001\right)$; (b) Scaptotrigona bipunctata $\left(\chi^{2}=596.4 ; \mathrm{df}=11 ; \mathrm{p}<0.001\right)$; (c) number of flowering plant species per strata during the year. The total number of bee individuals sampled per month is indicated in brackets. $\square$ lower; $\square$ upper. 


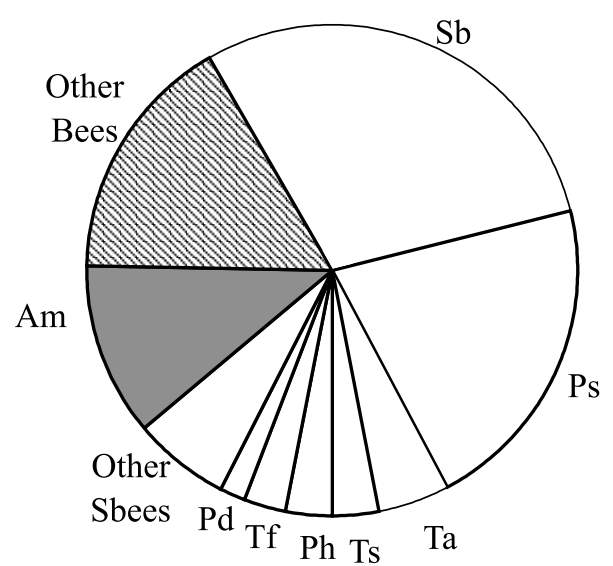

Figure 3. The relative abundance of stingless bee species $(n=17)$ and other bees-Apoidea $(n=156)$ on flowers in the Tropical Atlantic Rainforest. Other Sbees - other ten species of stingless bees. All stingless bee species are listed in Tab.1.

vertical distribution (Fig. 1): the association of Partamona helleri $\left(\chi^{2}=23.1 ; \mathrm{df}=1 ; \mathrm{p}<0.001\right)$ and Tetragonisca angustula $\left(\chi^{2}=19.3 ; \mathrm{df}=1 ; \mathrm{p}<0.001\right)$ with the upper stratum was significant; meanwhile, Trigona spinipes $\left(\chi^{2}=75.5 ; \mathrm{df}=1 ; \mathrm{p}<0.001\right)$ and T. fulviventris $\left(\chi^{2}=321.9 ; \mathrm{df}=1 ; \mathrm{p}<0.001\right)$ were foraging mainly within the lower stratum. The foraging distribution of Plebeia droryana is unpredictable $\left(\chi^{2}=0,874 ; \mathrm{df}=1\right.$; $\mathrm{p}=0,350)$. Detailed parametric analysis and discussion of vertical distribution of abundant species are presented in a complementary paper (Ramalho et al. in prep.).

Africanized Apis mellifera was also common on mass flowering plants with small flowers, however it represented less than $10 \%$ of all bee individuals sampled in the upper stratum of TAF. Large numbers of A. mellifera foragers were often sampled in trees growing along the sunny roadside. Roubik et al. (1995) assumed that Apis is not particularly "stratum constant", but is "more likely to discover resources in or near the upper canopy or boundary layer" in a tall tropical forest.

The patchy exploitation of mass-flowering crowns by stingless bees - Stingless bees are the dominant group of insects that visit flowers in the TAF (Fig. 3). These bees exploit most of the local melittophilous flora (73\% of the 96 plant species encountered) available to the Apoidea throughout the year in all forest strata. However, they harvest large quantities of nectar and pollen from just a few productive flowering plants $(15 \%$ of melittophilous species; Fig. 4). These highly visited plants flower in the upper stratum and often exhibit some degree of mass flowering (Tab. 3).

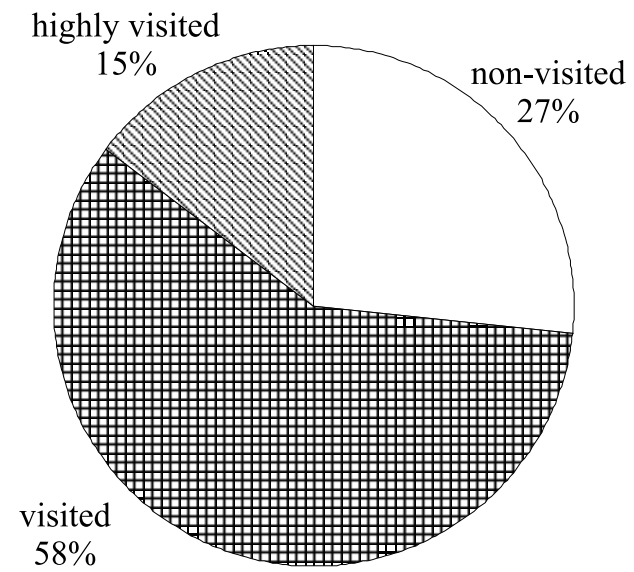

Figure 4. Proportion of melittophilous plant species $(n=96)$ visited or highly visited by stingless bees species (see Materials and Methods) in the Tropical Atlantic Rainforest.

In general the "highly visited" plants (Fig. 4) produce, over a short period of time, large numbers of flowers clustered in rich inflorescence (mass flowering species; Tab. 3). If one considers the flowering period per se, these "mass flowering" plants could be ranked in a continuum of phenological types, ranging from "big-bang" (e.g., Myrcia tomentosa DC.), which opened a large number of flowers in a few days, to "cornucopia" (e.g., Croton macrobothrys Baill.) with many flowers opened for several weeks (e.g., Gentry 1974b).

The "highly visited" mass-flowering trees (Fig. 4; Tab. 3) attracted more than $70 \%$ of all stingless bee individuals sampled on the flowers at Cantareira Forest. Most of them were also highly visited by beetles and flies. These trees were visited by all local 17 stingless bee species, and were highly shared by many of them. In number of individuals, stingless bees comprise more than $80 \%$ of the bees foraging on "highly visited" plants, Apis mellifera comprise $10 \%$, and other bee species less than $10 \%$. These other bees visiting the massflowering trees comprise 50\% of local Apoidea species (a total of 169 bee species) and most of them are small bees $(<1,0 \mathrm{~cm})$. The large or robust bees such as Bombus, Xylocopa, Centris and some Megachile are rarely sampled on the small flowers of these mass-flowering trees.

Almost all of these mass-flowering trees are hermaphrodites or monoecious, with tiny inconspicuous nectar flowers (Tab. 3). Small stingless bees often pollinate them: these plants have generalized flowers (radial symmetry and open corolla) whose fertile 


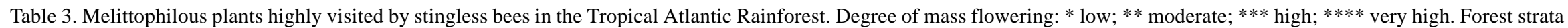
$=$ upper $(\mathrm{U})$ and lower $(\mathrm{L})($ see Material and Methods); Plant Habit = Tree $(\mathrm{T})$ and Liana $(\mathrm{L})$. Floral resources: pollen $(\mathrm{P})$ and/or nectar $(\mathrm{N})$; $(\mathrm{p})$ and $(\mathrm{n})$ indicate small amounts of pollen and nectar. Sexual system ${ }^{1}$ : plants whose sexual systems are displayed in capital letters are pollinated by stingless bees. Plant species visited by small beetles (B), flies (F), wasp (w) and small butterfly (l) with frequencies (in relation to stingless bees) higher than $10 \%(\bullet), 30 \%(\bullet \bullet)$ and $100 \%(\bullet \bullet \bullet)$ are indicated. All bee taxa are listed in Tab.1. Number of species in brackets.

\begin{tabular}{|c|c|c|c|c|c|c|c|c|c|}
\hline \multirow[t]{2}{*}{ Plant taxa } & \multirow{2}{*}{$\begin{array}{l}\text { Strata } \\
\text { Habitus } \\
\text { Height-m) }\end{array}$} & \multirow{2}{*}{$\begin{array}{c}\text { Floral } \\
\text { Resource }\end{array}$} & \multirow{2}{*}{$\begin{array}{l}\text { Sexual } \\
\text { System }\end{array}$} & \multirow{2}{*}{$\begin{array}{l}\text { Flower size } \\
\text { ngth } \times \text { diametes } \\
\quad(\mathrm{mm})\end{array}$} & \multirow[t]{2}{*}{ Stingless bees } & \multirow[t]{2}{*}{ Other bees } & \multirow{2}{*}{$\begin{array}{l}\text { Other } \\
\text { insects }\end{array}$} & \multicolumn{2}{|c|}{ Flowering } \\
\hline & & & & & & & & $\begin{array}{l}\text { Period I } \\
\text { (month) }\end{array}$ & Pattern \\
\hline ARALIACEAE & & & & & & & & & \\
\hline $\begin{array}{l}\text { Dendropanax cuneatum } \\
\text { Decne. \& Planch. }\end{array}$ & UT(12) & NP & HERMAPHRODITE & $3.0 \times 4.3$ & $\mathrm{Mm} ; \mathrm{Nt} ; \mathrm{Ps} ; \mathrm{Ph} ; \mathrm{Pr} ; \mathrm{Sb} ; \mathrm{Sq} ; \mathrm{Tc} ; \mathrm{Ta} ; \mathrm{Tf}$ & $\operatorname{Am} ; \mathrm{Hy}(3) ; \mathrm{Hc}(1)$ & $\mathrm{F} \bullet \bullet \mathrm{W}$ & Jun, Jul & $* * *$ \\
\hline $\begin{array}{l}\text { ASTERACEAE } \\
\text { Baccharis anomala DC. }\end{array}$ & UL(8) & $\mathrm{N}$ & dioecious & $1.3 \times 0.1$ & Mm;Ps;Pd;Pr;Sb;Sq;Ta;Tf;Ts & $\begin{array}{l}\mathrm{Am} ; \mathrm{Ce}(1) ; \mathrm{Ct}(3) ; \mathrm{Hy}(3) ; \mathrm{Ch}(1) \\
\mathrm{Hb}(1) ; \operatorname{Px}(1)\end{array}$ & $\mathrm{F} \bullet$ & Aug & $* * *$ \\
\hline Vernonia diffusa Less. & $\mathrm{UT}((9)$ & NP & HERMAPHRODITE & $4.9 \times 1.0$ & $\begin{array}{l}\mathrm{Mb} ; \mathrm{Mm} ; \mathrm{Mq} ; \mathrm{Mr} ; \mathrm{Pd} ; \mathrm{Ph} ; \mathrm{Ps} ; \mathrm{Sb} \\
\mathrm{Tc} ; \mathrm{Ts}\end{array}$ & $\begin{array}{l}\operatorname{Am} ; \operatorname{Ce}(2) ; \operatorname{Ct}(2) ; \operatorname{Ex}(2) ; \operatorname{Pte}(1) \\
\operatorname{Ac}(4)) ; \operatorname{Mch}(1)\end{array}$ & & Sep, Oct & $* * *$ \\
\hline $\begin{array}{l}\text { BURSERACEAE } \\
\quad \text { Protium widgrenii Engl. }\end{array}$ & $\mathrm{UT}(15)$ & $\mathrm{nP}$ & hermaphrodite & $1.0 \times 3.4$ & Ps;Pd;Pr;Sb;Sq;Ta;Tf;Ts & $\begin{array}{l}\operatorname{Am} ; \mathrm{Ct}(1) ; \operatorname{Pte}(1) ; \mathrm{Hy}(5) \\
\operatorname{Ln}(1) \mathrm{Hb}(1)\end{array}$ & $\mathrm{F} \bullet \bullet$ & Nov & $* *$ \\
\hline $\begin{array}{l}\text { CLETHRACEAE } \\
\text { Clethra scabra Pers. }\end{array}$ & UT(25) & NP & HERMAPHRODITE & $4.0 \times 4.1$ & $\mathrm{Mb} ; \mathrm{Mm} ; \mathrm{Nt} ; \mathrm{Ps} ; \mathrm{Pd} ; \mathrm{Ph} ; \mathrm{Pr} ; \mathrm{Sb} ; \mathrm{Sq} ; \mathrm{Ta}$ & $\begin{array}{l}\mathrm{Am} ; \mathrm{Ct}(4) ; \mathrm{Co}(1) ; \mathrm{Hy}(4) ; \mathrm{Ac}(2) \\
\operatorname{Di}(3) ; \mathrm{Hb}(2) \\
\mathrm{Nc}(2\end{array}$ & $\begin{array}{l}\mathrm{B} \bullet \bullet \bullet \\
\mathrm{F} \bullet \bullet \bullet\end{array}$ & Jan & $* *$ \\
\hline $\begin{array}{l}\text { EUPHORBIACEAE } \\
\text { Croton floribundus Spreng. }\end{array}$ & UT(7) & NP & MONOECIOUS & $5.8 \times 7.7$ & $\mathrm{Mb} ; \mathrm{Mm} ; \mathrm{Mq} ; \mathrm{Mr} ; \mathrm{Ph} ; \mathrm{Ps} ; \mathrm{Sb} ; \mathrm{Sq} ; \mathrm{Ts}$ & $\begin{array}{l}\text { Am;Pte(1); } \operatorname{Te}(1) ; \operatorname{Han}(1) ; \operatorname{Hy}(1) ; \\
\operatorname{Ac}(4) ; \operatorname{Ch}(1) ; \operatorname{Nc}(1) ; \operatorname{Rc}(2) ; \operatorname{Cx}(2) ; \\
\operatorname{Mch}(5)\end{array}$ & & Dec & $* * * *$ \\
\hline Croton macrobothrys Baill. & $\mathrm{UT}(30)$ & NP & MONOECIOUS & $3.0 \times 4.7$ & Ps;Pd;Pr;Sb;Sq;Tc;Ts & $\begin{array}{l}\text { Am;Bo(1);Ce(1);Ct(1); } \\
\operatorname{Pte}(1) ; \operatorname{Hy}(3) ; \operatorname{Ln}(1) ; \\
\operatorname{Ac}(7) ; \operatorname{Di}(1) ; \operatorname{Rc}(3) ; \operatorname{Ant}(1) \\
\text { Mch(1)Pan(1) }\end{array}$ & $\begin{array}{l}\mathrm{B} \bullet \bullet \bullet \mathrm{W} \\
\mathrm{F} \bullet \bullet \bullet\end{array}$ & Oct, Nov & $* * * *$ \\
\hline Sapium glandulatum (Vell.) Pax & x UT(20) & $P$ & MONOECIOUS & $2.2 \times 1.6$ & Gs;Ps;Pd;Pr;Sb;Sq;Tc;Ta & $\begin{array}{l}\mathrm{Am} ; \mathrm{Ct}(2) ; \mathrm{Hy}(4) ; \operatorname{Ac}(3) ; \operatorname{Acd}(1) \\
\mathrm{Ch}(1) ; \operatorname{Di}(2) ; \operatorname{Hb}(2) ; \operatorname{Px}(1)\end{array}$ & & Oct, Nov & $* * *$ \\
\hline $\begin{array}{l}\text { FABACEAE } \\
\quad \text { Machaerium nictitans Benth. }\end{array}$ & $\mathrm{UT}(30)$ & $\mathrm{N}$ & hermaphrodite & $4.4 \times 4.4$ & $\mathrm{Mm} ; \mathrm{Mq} ; \mathrm{Mr} ; \mathrm{Ps} ; \mathrm{Ph} ; \mathrm{Sb} ; \mathrm{Tf} ; \mathrm{Ts}$ & $\begin{array}{l}\mathrm{Am} ; \mathrm{Bo}(1) ; \mathrm{Ct}(1) ; \operatorname{Ln}(1) ; \\
\mathrm{Ac}(1) \mathrm{Hb}(2) ; \mathrm{Nc}(1) ; \mathrm{Cx}(1)\end{array}$ & $\mathrm{F} \bullet \mathrm{w} 1$ & Apr & $* *$ \\
\hline $\begin{array}{l}\text { FLACOURTIACEAE } \\
\text { Casearia sylvestris } \mathrm{Sw} . \\
\text { LAURACEAE }\end{array}$ & $\mathrm{UT}(7)$ & $\mathrm{P}$ & HERMAPHRODITE & $1.8 \times 2.7$ & $\mathrm{Mb} ; \mathrm{Mm} ; \mathrm{Mr} ; \mathrm{Pd} ; \mathrm{Ph} ; \mathrm{Ps} ; \mathrm{Sb} ; \mathrm{Sq} ; \mathrm{Tf} ; \mathrm{Ts}$ & Am & & Sep & $* *$ \\
\hline Ocotea puberula (Rich.) Nees & UT(18) & NP & ANDROMONOECIOUS & S $1.3 \times 2.0$ & $\mathrm{Nt} ; \mathrm{Ps} ; \mathrm{Ph} ; \mathrm{Pd} ; \mathrm{Pr} ; \mathrm{Sb} ; \mathrm{Sq} ; \mathrm{Ta} ; \mathrm{Ts}$ & $\begin{array}{l}\mathrm{Ce}(1) ; \mathrm{Hy}(4) ; \operatorname{Ac}(2) ; \mathrm{Ch}(2) \\
\mathrm{Hb}(2) ; \operatorname{Nc}(2) ; \operatorname{Px}(1)\end{array}$ & $\mathrm{F} \bullet \bullet \mathrm{w}$ & Jul, Aug & $* * *$ \\
\hline $\begin{array}{l}\text { MYRTACEAE } \\
\text { Myrcia tomentosa DC. } \\
\text { RUBIACEAE }\end{array}$ & $\mathrm{LT}(5)$ & $\mathrm{N}$ & HERMAPHRODITE & $2.5 \times 4.5$ & $\mathrm{Mb} ; \mathrm{Mq} ; \mathrm{Pd} ; \mathrm{Ph} ; \mathrm{Pr} ; \mathrm{Sb} ; \mathrm{Sq} ; \mathrm{Ts}$ & $\mathrm{Am}$ & & Oct & $* * *$ \\
\hline $\begin{array}{l}\text { Bathysa meridionalis } \\
\text { L.B.Smith \& Downs }\end{array}$ & $\mathrm{UT}(7)$ & $\mathrm{N}$ & HERMAPHRODITE & $2.7 \times 2.2$ & $\mathrm{Mb} ; \mathrm{Mm} ; \mathrm{Mq} ; \mathrm{Mr} ; \mathrm{Ps} ; \mathrm{Ph} ; \mathrm{Pd} ; \mathrm{Sb}$ & $\mathrm{Am}$ & & Nov & $*$ \\
\hline $\begin{array}{l}\text { SAPINDACEAE } \\
\text { Matayba elaeagnoides Radlk. }\end{array}$ & $\mathrm{UT}(15)$ & NP & MONOECIOUS & $1.5 \times 2.1$ & $\mathrm{Mm} ; \mathrm{Nt} ; \mathrm{Ps} ; \mathrm{Pd} ; \mathrm{Sb} ; \mathrm{Sq} ; \mathrm{Th} ; \mathrm{Ts}$ & $\begin{array}{l}\mathrm{Am} ; \mathrm{Ct}(1) ; \mathrm{Co}(1) ; \mathrm{Hy}(7) ; \operatorname{Ln}(1) ; \\
\mathrm{Hb}(1)\end{array}$ & $\mathrm{B} \bullet \mathrm{F} \bullet \bullet \mathrm{w} 1$ & Oct, Nov & $* *$ \\
\hline Serjania reticulata Cambess. & $\mathrm{UL}(8)$ & $\mathrm{Np}$ & MONOECIOUS & $2.8 \times 3.3$ & $\mathrm{Mr} ; \mathrm{Ps} ; \mathrm{Sb} ; \mathrm{Sq}$ & $\mathrm{Cn}(1) ; \mathrm{Hy}(5) ; \mathrm{Ac}(1) ; \mathrm{Hb}(2) ; \mathrm{Nc}(2)$ & & Mar & $* *$ \\
\hline
\end{tabular}


structures match well with stingless bee body size and their harvesting moves.

\section{Discussion}

Stratification, dominance and patchy foraging of stingless bees in the TAF - Plant species showing mass flowering were observed mainly within the upper strata and/or along open roadsides in the Cantareira Forest $(>7 \mathrm{~m}$ height; e.g., Tab. 3). Baker et al. (1983) suggest that "mass flowering" is most appropriate for canopy trees and lianas, which attract animals flying above the forest canopy. Several authors have assumed that mass flowering is an expensive reproductive strategy, available mainly to the canopy species exposed to direct sunlight.

Stingless bees are "pre-adapted" to foraging while exposed to direct sunlight due to their large surface/ volume ratio. Roubik (1993b) stated that their association with the upper stratum was unpredictable due to their generalist feeding habits and opportunistic foraging. This "opportunistic stratification hypothesis" was based on long-term bee sampling undertaken on Barro Colorado Island, Panama. However, the light trap census employed in that work likely gives an inadequate picture of the foraging activity and therefore stratification of diurnal bees such as stingless bees.

In the Cantareira forest, Paratrigona subnuda and Scaptotrigona bipunctata were five to ten times more abundant than any other stingless bee, thus offering an opportunity to test Roubik's hypothesis. P. subnuda is more frequent at the lower stratum during shortage periods of mass flowering trees, therefore it behave according to the Roubik's opportunistic stratification hypothesis. S. bipunctata exhibit a constant fidelity to the upper stratum throughout the year because its preferred flowering plants (mass flowering) are stratified in the TAF. Its foraging pattern satisfies an alternative predictable stratification hypothesis. This species behave like the high-density specialists of Johnson \& Hubbell (1975), and it seemed more prone to forage on mass flowering plants in the upper stratum than did P. subnuda.

It is noteworthy that the association of $P$. subnuda and S. bipunctata with the upper stratum and with mass flowerings trees can hardly be subsumed to any special and shared behavior of these stingless bees. They are both very small bees ( $<6 \mathrm{~mm}$ in length) and live in large colonies (5.000 to 20.000 workers). By contrast, they choose very distinct nesting sites (underground vs. tree hollows) and exhibit different abilities to communicate food sources and to group foraging (Lindauer \& Kerr
1960; Nogueira-Neto 1970; Johnson \& Hubbell 1974; 1975; Johnson 1982; Sakagami 1982; Ramalho et al. 1991). In synthesis, behavioral specialization was not sufficient to predict the actual association of these stingless bees with mass flowering trees in the upper stratum.

Trigona fulviventris was also associated with the lower stratum in Cantareira Forest and in the Panamanian forest (Roubik 1993b), making it a good candidate for experimental field analysis of lower stratum fidelity.

The abundance of other bee groups in the upper stratum of the Cantareira Forest was inversely related to the vertical distribution of stingless bees. Robust and long-tongued bees, such as some Anthophoridae and Megachilidae, can avoid resource sharing with stingless bees by visiting large flowers, or flowers with a long corolla, in the canopy (Frankie et al. 1983) or the understorey. Small Anthophoridae and Megachilidae as well as small and short-tongued bees, like most Halictidae, must visit small flowers and/or those with a short corolla. As a result, these bee groups have less chance of avoiding resource sharing with generalist stingless bees. It is noteworthy that small Anthophoridae, Megachilidae and Halictidae bees are less abundant in the upper stratum than would be predicted by the availability of small flowers: the same mass flowering very attractive to stingless bees. This vertical displacement is analyzed in another paper, and it is attributed to uneven vertical distribution of floral source quality, per se, and/or to antagonism between stingless bees and small non social bees (Ramalho et al. in prep.).

The selective exploitation of rich food sources by many stingless bees is demonstrated by field census and data on group foraging behavior (Johnson \& Hubbell 1974; 1975; Hubbell \& Johnson 1978; Johnson 1982; Johnson et al. 1987), and monitoring of floral sources allocation by colonies (Ramalho 1990; Ramalho et al . 1989; 1990; 1991; Roubik 1993a). By storing surplus nutrients collected from a few selected rich massflowering sources (Tab. 3, Fig. 4), they can maintain very large colonies and high populations throughout the year. As a result, during shortages of these rich sources in the upper stratum (February, March and December at Cantareira Forest), the stingless bees should spread their foraging pressure and overexploit poorer resources in the upper or lower stratum of the forest, which are normally more attractive to non-social bees (Tab. 2; Ramalho et al. in prep.).

Self-pollinators (inefficient cross-pollinators)? - Because stingless bees are small-generalized flower visitors, some 
authors have suggested they are robbers or thieves (Janzen 1975; Renner 1983; Inouye 1980). Others view them as generalized pollinators of the most visited plant species (Roubik 1979; Wille 1983). Stinglesss bees pollinated most of hermaphroditic or monoecious mass flowering trees with small nectar flowers in the TAF canopy, yet it is unknown if they promote self-pollination (autogamy and/or geitonogamy) or cross-pollination of these trees.

The presumed poor ability of stingless bees to act as cross-pollinators should not be related with their supposed limitation to perform inter-canopy flights, as have been suggested by Bawa and others (Bawa 1980;1990; Renner \& Feil 1993). In spite of their small body size, most stingless bee colonies have a potential home range of 500 to 4,000m (Roubik \& Aluja 1983; Wille 1983; Van Niewstadt \& Iraheta 1996). The medium-large sized foragers of Apis koschevnikovi Buttel-Reepen and Apis dorsata Fabricius are considered efficient cross pollinators because they effect pollen exchange between forest trees within an area at least 640m diam. (Roubik et al. 1995). In TAF, many mass-flowering plants highly visited by stingless bees were found inside the sampling plot (30ha) with a distance of less than $500 \mathrm{~m}$ between co-specifics (e.g. Baccharis anomala DC., Croton floribundus Spreng., Dendropanax cuneatum Decne. \& Planch, Croton macrobothrys Baill., Machaerium nictitans Benth., Matayba elaeagnoides Radlk., Ocotea puberula (Rich) Nees, Serjania reticulata Cambess., and Vernonia diffusa Less.).

Group foraging (Lindauer \& Kerr 1960; Johnson \& Hubbell 1974; 1975) and ability of storing food surplus within colonies favor the exhaustive foraging of stingless bees on patchy rich floral sources as the mass-flowering crowns for several days. These patchy and rich sources should easily satiate small bee foragers (Poursin 1982) and stimulating floral constancy (Ramalho et al. 1994). As a result, mass flowering pattern should improve local fidelity and reduce the chance that the stingless bee foragers fly between crowns during the same foraging trip and initiate cross-pollination. In synthesis, foraging and colony economics of stingless bees and not flight range are constraints to cross-pollinating of mass-flowering trees.

Interestingly, group or aggressive behavior of stingless bee foragers (Johnson \& Hubbell 1974; 1975; Johnson 1982) could provoke inter-canopy flights of other bees (Mori \& Pipoly 1984). Although, mass flowering trees in the TAF also attracted many other bee species
(50\% of all local Apoidea species), the observed high rate of fruiting on several tree crowns should not be related to the cross-pollination activities of these "other bees" because almost all of them are also small bees (body length $<10 \mathrm{~mm}$ ). Large or robust bees, such as Xylocopa, Bombus, Centris and some Megachile (all potential cross-pollinators) are very rarely sampled on these mass flowering trees with small flowers.

In the TAF, fruiting is plentiful on several massflowering crowns dominated by stingless bees (e.g., C. floribundus, C. macrobothrys, O. puberula), which should be attributed to the efficient selfpollination services (autogamy and geitonogamy) and more rarely to cross-pollination activities.

Dioecy is not biased towards mass flowering trees with small flowers in the TAF - According to the Bawa hypothesis, stingless bees and other "small diverse" or generalized insects have contributed to the abundance of dioecy among tropical forest trees (Bawa 1980; 1990; Baker et al. 1983). This hypothesis has been generally accepted, but not adequately tested (Renner \& Feil 1993).

Clearly, in the TAF, the foraging pressure of stingless bees is not biased towards the dioecious tree crowns. Moreover, dioecious species represents less than $6 \%$ of plant species highly visited by stingless bees (Wilms et al. 1996), which are far below the frequency of dioecious trees in the Neotropical forests (Baker et al. 1983; Kress \& Beach 1994). Therefore, if most of the trees that are experiencing the highest foraging pressure by stingless bees are not dioecious, why would other plant species that these bees visit be different?

Assuming that the potential for self-pollination is greatest among mass-flowering crowns (Snow et al. 1996), these trees should be able to take advantage of the abundant local pollinating services of the stingless bees (Fig. 4; Tab. 3) if they are self-compatible, or if they exhibit partial self-incompatibility. This selffacilitation hypothesis predicts that the highest frequency of facultative inbreeding (or partial self-incompatibility) would be found among melittophilous mass flowering trees with tiny flowers in the upper stratum of TAF. Personal observation on $C$. macrobothrys and $O$. puberela support this hypothesis: after being visited mainly by stingless bees, these locally abundant trees produced huge amounts of small fruits (more than 1,000 fruits $/ \mathrm{m}^{2} /$ crown), most likely through autogamy and/or geitonogamy.

A partial test of the self-facilitation hypothesis comes from La Selva studies. This is a "tropical forest site for which there is a systematic enumeration of 
pollination systems for a large portion of the taxa" (Kress $\&$ Beach 1994), and for which there is information concerning plant reproductive as well as pollination systems stratification. Dioecy and self-incompatibility are respectively two and three times more frequent in the upper stratum (over $5 \mathrm{~m}$ ) than in the lower stratum (Kress \& Beach 1994). Likewise, "small bee" and "small diverse insect" pollination systems, which involve stingless bees, are also three to five times more frequent in upper stratum (Bawa et al. 1985). Therefore, vertical distribution of self-incompatibility fits better than dioecy the observed vertical foraging distribution of stingless bees in the La Selva Forest.

Niche preemption by stingless bees: the role of mass flowerings trees - The hypothesis of "niche preemption" (Roubik 1992) is derived fundamentally from the apparent predominance and ubiquitous presence of stingless bees in the tropical forest, where they exploit the melittophilous flowers and the other floral syndromes. In contrast, the idea of diffuse "co-evolution" (Wilms et al. 1997) emphasizes the association between stingless bees and mass-flowering trees.

The tight relationship of stingless bees with massflowering trees in the TAF should more properly be in the center of those alternative explanations. Massflowering trees with tiny flowers are often pollinated by stingless bees (Tab.3), which favor the hypothesis of co-evolution. However, the high overlap between stingless bees and other abundant small diverse insects (beetles and flies) on several mass flowering trees is likely an ecological effect of "niche preemption": for example, during three years of field observations, thousands of stingless bee foragers and the beetle Chauliognathus flavipes F. (Cantharidae) dominated alternate crowns of Croton macrobothrys (Euphorbiaceae), the most abundant mass-flowering tree at Cantareira Forest.

So, we can conclud that the foraging stratification of stingless bees within tropical forests is a predictable phenomenon when the following conditions are satisfied: these bees are locally abundant; their preferred floral resources are stratified; and the largest standing crop of pollen and nectar is in the upper stratum. These conditions are satisfied in the Tropical Atlantic Rainforest.

The fact that dioecy is common in tropical trees cannot be related to the foraging activity of stingless bee, nor with their supposed poor ability to promote crosspollination. A biased distribution of dioecy among mass flowering trees with small, inconspicuous flowers in the upper stratum and whose crowns those bees dominate would be expected. Clearly, stingless bees are not associated with dioecious mass-flowering trees in the TAF.

The self-facilitation hypothesis offers a better explanation on the role of stingless bees as pollinators of monoecious or hermaphrodite mass flowering trees in the TAF.

The tight relationship and likely diffuse co-evolution between stingless bees and mass-flowering trees (with small flowers) is more properly in the center of a process of niche preemption by gradual replacement of unpredictable, generalist, and poor pollinators (e.g. small beetles) by predictable ones (stingless bees).

\section{Acknowledgments}

The author acknowledges Dra. Vera Lúcia Imperatriz Fonseca (IBIO, USP, SP), Dr. Hayo H.W. Vellthuis (Universidade de Utrecht, Netherlands) and MSc. Milson dos Anjos Batista (UFBA), for their contributions.

\section{References}

Aguiar,C. M. L. \& Martins,C. F. 1997. Abundância relativa, diversidade e fenologia de abelhas (Hymenoptera, Apoidea) na Caatinga, São João do Cariri, Paraíba, Brasil. Iheringia, Serie Zoologia 83: 151-163

Baker, H. G.; Bawa, K. S.; Frankie, G. W. \& Opler, P. A. 1983. Reproductive biology of plants in tropical forests. Pp. 183-215. In: F. B. Golley (ed.). Tropical rainforest ecosystems. Ecosystems of the World 14A. Elsevier Scientific Publ Co, New York.

Baitello, J. B.; Aguiar, O. T.; Rocha, F. T.; Pastore, J. A. \& Esteves, R. 1993 Estrutura fitossociológica da vegetação arbórea da Serra da Cantareira (SP). Revista do Instituto Florestal 5: 133-161.

Barbola, I. F. \& Laroca, S. 1993. A comunidade de Apoidea (Hymenoptera) da Reserva Passa Dois: I. Diversidade, abundância relativa e atividade sazonal. Acta Biologica Paranaense 22: 91-113.

Bawa, K. S. 1980. Evolution of dioecy in flowering plants. Annual Review of Ecology and Systematics 11: 15-39.

Bawa, K. S. 1990. Plant-pollinator interactions in tropical rain forests. Annual Review of Ecology and Systematics 21: 399-422.

Bawa, K. S.; Bullock, S. H.; Perry, D. R.; Coville, R. E. \& Grayum, M. H. 1985. Reproductive biology of tropical lowland rain forest trees. II. Pollination systems. American Journal of Botany 72: 346-356

Bortoli, C. \& Laroca, S. 1990. Estudo biocenótico em Apoidea (Hymenoptera) de uma área restrita em São José dos Pinhais (PR, sul do Brasil), com notas comparativas. Dusenia 15: 1-112. 
Frankie, G. W. \& Haber, W. A. 1983. Why bees move among mass flowering Neotropical trees. Pp. 360-72. In: C. E. Jones \& R. J. Little (eds.). Handbook of experimental pollination biology. Van Nostrand Reinhold, New York.

Frankie, G. W.; Haber, W. A.; Opler, P. A. \& Bawa, K. S. 1983. Characteristics and organization of the large bee pollination system in the Costa Rican dry forest. Pp. 360-72. In: C. E. Jones \& R. J. Little (eds.). Handbook of experimental pollination biology. Van Nostrand Reinhold, New York.

Gentry, A. H. 1974a. Coevolutionary patterns in Central American Bignoniaceae. Annals of the Missouri Botanical Garden 61: 728-759.

Gentry, A. H. 1974b. Flowering phenology and diversity in tropical Bignoniaceae. Biotropica 6: 64-68.

Hubbell, S. P. \& Johnson, L. K. 1978. Comparative foraging behavior of six stingless bees species exploiting a standardized resource. Ecology 59: 1123-1136.

Inouye, D. W. 1980. The terminology of floral larceny. Ecology 61: 1251-1253.

Janzen, D. H. 1975. Ecology of plants in the tropics. Edward Arnold, London.

Johnson, L. K. 1982. Patterns of communication and recruitment in stingless bees. Pp. 323-34. In: M. D. Breed; C. D. Michener \& H. E. Evans (eds.). The biology of social insects. Westview Press, Boulder.

Johnson, L. K. \& Hubbell, S. P. 1974. Aggression and competition among stingless bees: field studies. Ecology 55: $120-127$.

Johnson, L. K. \& Hubbell, S. P. 1975. Contrasting foraging strategies and coexistence of two bee species on a single resource. Ecology 56: 1398-1406

Johnson, L. K.; Hubbell, S. P. \& Feener, D. H. 1987. Defense of food supply by eusocial colonies. American Zoologist 27: 347-358.

Kress, W. J. \& Beach, J. H. 1994. Flowering plant reproductive systems. Pp. 161-182. In: L. A. McDade; K. S. Bawa; H. A. Hespenheide \& G. S. Hartshorn (eds.). La Selva. Ecology and Natural History of a Neotropical Rain Forest. The University of Chicago Press, Chicago.

Lindauer, M. \& Kerr, W. E. 1960. Communication between workers of stingless bees. Bee World 41: 29-41.

Martins, C.F. 1994. Comunidade de abelhas (Hymenoptera, Apoidea) da caatinga e do cerrado com elementos de campo rupestre do Estado da Bahia, Brasil. Revista Nordestina de Biologia 9: 125-131.

Michener, C. D. 1979. Biogeography of the bees. Annals of the Missouri Botanical Garden 66: 277-347.

Michener, C. D. \& Grimaldi, D. A. 1988. A Trigona from late Cretaceous amber of New Jersey (Hymenoptera: Apidae: Meliponinae). American Museum Novitates 2917: 1-10

Mori, S. A. \& Pipoly, J. J. 1984. Observations on the big bang flowering of Miconia minutiflora (Melastomataceae). Brittonia 36: 330-341.
Nogueira-Neto, P. 1970. A criação de abelhas indígenas sem ferrão. $2^{\mathrm{a}}$ ed. Editora Tecnapis, São Paulo.

Por, F. D. 1992. Sooretama: the Atlantic Rainforest of Brasil. SBC Academic Publ., The Netherlands.

Poursin, M. S. 1982. Niches écologiques de quelques Halictinae. II. Régimes alimentaires. Apidologie 13: 227-240.

Ramalho, M. 1990. Foraging by stingless bees of the genus Scaptotrigona (Apidae, Meliponinae). Journal of Apicultural Research 29: 61-67.

Ramalho, M. 1998. Os meliponíneos na Floresta Atlântica: efeitos potenciais da pressão de forrageio sobre sistemas reprodutivos de árvores com floradas maciças. Pp. 75-81. In: Anais do Encontro sobre Abelhas 3. Ribeirão Preto, 1998. USP, São Paulo.

Ramalho, M.; Giannini, T. C.; Malagodi-Braga, K. S. \& Imperatriz-Fonseca, V. L. 1994. Pollen harvest by stingless bee foragers (Hymenoptera, Apidae, Meliponinae). Grana 33: 239-244.

Ramalho, M.; Kleinert-Giovannini, A. \& Imperatriz-Fonseca, V. L. 1989. Utilization of floral resources by species of Melipona (Apidae, Meliponinae): floral preferences. Apidologie 20: 185-95.

Ramalho, M.; Kleinert-Giovanini, A. \& Imperatriz-Fonseca, V. L. 1990. Important bee plants for stingless bees (Melipona and Trigonini) and Africanized honeybees (Apis mellifera) in neotropical habitas: a review. Apidologie 21: 469-488.

Ramalho, M.; Kleinert-Giovanni, A.; Imperatriz-Fonseca, V. L. 1991. Ecologia alimentar de abelhas sociais. In: J. R. Parra \& A. R. Panizzi (org.). Ecologia nutricional de insetos e suas implicações no manejo de pragas. Ed. Manole \& CNPq, São Paulo \& Brasília.

Renner, S. 1983. The widespread occurence of anther destruction by Trigona bees in Melastomataceae. Biotropica 15: 251-256.

Renner, S. \& Feil, J. P. 1993. Pollinators of tropical dioecious angiosperms. American Journal of Botany 80: 1100-1107.

Roubik, D. W. 1979. Africanized honey bees, stingless bees, and the structure of tropical plant-pollinator communicites. Pp. 403-417. In: Proceedings of the IV Internationl Symposium on Pollination. Maryland Agricultural Experimental Station Misc. Publ. 1. Maryland, USA.

Roubik, D. W. 1992. Loose niches in tropical communities: why are there so few bees and so many trees? Pp. 327-354. In M. D. Hunter; T. Ohgushi \& P. W. Price (eds.). Effects of resource distribution on animal-plant interactions. Academic Press, San Diego.

Roubik, D. W. 1993a. Direct costs of forest reproduction, bee-cycling and the efficiency of pollination modes. Journal of Biosciences 18: 537-552.

Roubik, D. W. 1993b. Tropical pollinators in the canopy and understory: field data and theory for stratum "preferences". Journal of Insect Behaviour 6: 659-73.

Roubik, D. W. \& Aluja, M. 1983. Flight ranges of Melipona and Trigona in tropical forest. Journal of the Kansas Entomological Society 56: 217-222. 
Roubik, D. W.; Inoue, T. \& Hamid, A. A. 1995. Canopy foraging by two tropical honeybees: bee height fidelity and tree genetic neighborhoods. Tropics 5: 81-93.

Sakagami, S. F. 1982. Stingless bees. Pp. 361-423. In: H. R. Herman (ed.). Social insects. Academic Press Inc., New York.

Silveira, F. A. \& Campos, M. J. O. 1995. A melissofauna de Corumbataí (SP) e Paraopeba (MG) e uma análise da biogeografia das abelhas do cerrado Brasileiro (Hymenoptera, Apoidea). Revista Brasileira de Entomologia 3: 371-401.

Silveira, F.; Rocha, L. B.; Cure, J. R. \& Oliveira, M. J. F. 1993. Abelhas silvestres (Hymenoptera, Apoidea) da zona da mata de Minas Gerais. II. Diversidade, abundância e fontes de alimento em uma pastagem abandonada em Ponte Nova. Revista Brasileira de Entomologia 37: 595-610.

Snow, A. A.; Spira, T. P.; Simpson, R. \& Klips, R. A. 1996. The ecology of geitonogamus pollination. Pp. 191-216. In: D. G. Lloyd \& S. C. H. Barrett (eds.). Floral biology. Studies on floral evolution in animal-pollinated plants. Chapman \& Hall, New York.
VanNieuwstadt, M. G. L. \& Iraheta, C. E. R. 1996. Relation between size and foraging range in stingless bees (Apidae, Meliponinae). Apidologie 27: 219-228.

Viana, B. F.; Kleinert, A. D. P. \& Imperatriz-Fonseca, V. L. 1997. Abundance and flower visits of bees in cerrado of Bahia, tropical Brazil. Studies on Neotropical Fauna and Environment 32: 212-219.

Wille, A. 1983. Biology of stingless bees. Annual Review of Entomology 28: 41-64.

Wilms, W.; Imperatriz-Fonseca, V. L. \& Engels, W. 1996. Resources partitioning between higly eusocial bees and possible impact of the introduced Africanized honey bee on native stingless bees in the Brazilian Atlantic rainforest. Studies on Neotropical Fauna and Environment 31: 137-151

Wilms, W.; Ramalho, M. \& Wendel, L. 1997. Stingless bees and Africanized honey bees in the Mata Atlântica rainforest of Brazil. Pp. 167-170. In: XXXth International Apicultural Congress of Apimondia. Antuérpia. 